\title{
Clinico-Pathological Studies in Some Respiratory Diseases in Newly Born Buffalo Calves
}

Abdulla O.A.M. ${ }^{1}$, Omnia E. Kilany ${ }^{1}$, Amina A. Dessouki ${ }^{2}$, and Nehal A. Mohmoud ${ }^{1}$.

${ }^{1}$ Department of clinical pathology and ${ }^{2}$ Department of pathology, Faculty of Veterinary Medicine, Suez Canal University.

\section{Abstract}

A Total of 40 buffalo calves aged from 2 weeks to 3 months were used in this study. The animals were divided into two main groups the first group (group I) represented as a control group. The second group (group II) showed the clinical signs of pneumonia (natural diseased non- treated). Group (II) was subdivided into two subgroups: the first subgroup (group A) naturally diseased and treated with florofenicol (Nuflor), and the second subgroup (group B) naturally diseased and treated with tulathromycin (Draxxin).

Concerning the hematological findings of the diseased non treated group (II) revealed anemia in addition to neutrophilic leukocytosis with increase in both TNF- $\alpha$, IL-6 and decrease in both IgG and IgM levels was observed compared to control healthy group. While subgroups (A \& B) revealed increase in RBCs count, $\mathrm{Hb}$ concentration, PCV, MCHC, IgG and IgM and decrease in MCV, MCH, TNF- $\alpha$ and IL- 6 compared with diseased non treated group (II). Diseased treated subgroups (A\&B) revealed decrease in T.L.C, neutrophil and monocytes with increase of lymphocytes, basophils, eosinophils and platelets count compared with diseased non treated group (II). The diseased treated subgroup (B) with Draxxin exhibited improvement in hematological and immunological parameters analysis compared with the diseased treated subgroup (A) with Nuflor. The lungs of dead calves with respiratory diseases were examined microscopically. The obtained results were lung edema, hemorrhage, collapse and different types of pneumonia such as catarrhal, suppurative, fibrinous and interstitial pneumonia. Associated bronchial lymph nodes showing congestion of blood vessels and hyperplasia of lymphocyte cells.

\section{Introduction:-}

Bovine respiratory disease (BRD) is an infectious disease resulting from interactions of multiple predisposing stress factors, viral and bacterial agents Autio et al (2007). There are a number of viral agents that cause BRD such as bovine viral diarrhoea virus (BVDV) and infectious bovine rhinotracheitis virus (IBR) Malazdrewich (2001). $P$. haemolytica $P$. multocida are the most frequently bacterium isolated 
from the bovine respiratory disease BRD Griffin et al (2010). The acute onsets of pneumonia are characterized by severe changes in blood gases, erythrocytic parameters and leukogram parameters.

Neutrophils in lungs respond to acute inflammation with a series of reactions ended by pathogen destruction Soethout et al (2002). Moreover, Monocytes and macrophages produced proinflammatory cytokines (TNF- $\alpha$ and IL-6) mediating the effect of acute phase protein APP, favoring Thelper cell differentiation that construct a bridge between innate resistance and adaptive immunity (Trinchieri, 2003).

Aim of work: The study aimed to determine:

A- The hematological and immunological parameters analysis in the affected cases before treatment and after treatment with two types of antibiotics (Nuflor and Draxxin).

B- Determine the efficacy of the two antibiotics used in the treatment.

C- Histopathological examination for dead calves which suffering from respiratory manifestation.

\section{Materials and Methods}

This study was carried out on 40 newly born buffalo calves belonged to Faculty of Veterinary Medicine Farm, Suez Canal University, Ismailia from June 2013 to June
2014. The buffalo calves were reared in closed system each one in a separate partition. The age of buffalo calves was ranged from 2 weeks to 3 months. The calves were fed on whole milk two times daily. They began to fed on starter concentrated ration and roughage from the fourth week. The animals was divided into two main groups the first group (group I) included 10 calves represented as a control healthy group. The second group (group II) included 30 calves showed the clinical signs of pneumonia (natural diseased nontreated). The second group (group II) was subdivided into two subgroups: the first subgroup (group A) included 15 calves were naturally diseased and treated with florofenicol (Nuflor) and the second subgroup (group B) included 15 calves were naturally diseased and treated with tulathromycin (Draxxin).

\section{Blood Sampling:}

Blood samples were obtained from healthy and diseased calves before and 48hours after treatment by Jugular puncture for hematological and immunological parameters analysis. Each sample was divided into two tubes. The first tube contains (EDTA) as anticoagulant for hematological parameters analysis. The second tube without anticoagulant for serum separation for immunological parameters analysis.

Hematological Parameters
analysis:


Erythrocytes count, $\mathrm{Hb}$ concentration, PCV value, blood indices (MCV value, $\mathrm{MCH}$ value, $\mathrm{MCHC}$ ), total leukocytic count and differential leukocytic count were performed by manual method according to Jain (1986). The percentage and absolute value for each type of white cells were calculated according to Feldman et al (2000).

\section{Immunological} analysis:

- IgG \& IgM was determined according to Jovin et al (1971), Interleukin estimation IL-6 was determined from undiluted serum samples according to Chan and Perlstein (1987).Tumor necrosis factor- $\alpha$ (TNF- $\alpha$ )was determined according to Wajant et al (2003). Histopathological examination: The specimens were collected from lungs and associated bronchial lymph nodes of dead calves suffered from respiratory manifestation and they were immediately fixed in $10 \%$ phosphate buffer formalin and processed in histopathological techniques according to Drury and Willington (1980).

Statistical Analysis:-

The obtained data were subjected to independent t-test (between independent samples) and paired ttest (between dependent samples) to evaluate the effect of respiratory diseases in newly born buffalo calves. Differences between means were tested at the $5 \%$ and $1 \%$ probability level (significance level). All the statistical analysis were done using SPSS program version 17 (SPSS, Richmond, VA, USA) as described by Dytham (1999).

Table 1: Experimental design.

\begin{tabular}{|c|c|c|}
\hline Groups & Infection & Treatment \\
\hline (Group I) & $\begin{array}{c}\text { Not infected } \\
\text { (control healthy) }\end{array}$ & Not treated \\
\hline (Group II) & $\begin{array}{c}\text { Naturally diseased } \\
\text { (before treatment) }\end{array}$ & Not treated \\
\cline { 2 - 3 } & $\begin{array}{c}\text { Subgroup (Group A) } \\
\text { Naturally diseased and } \\
\text { treated with Nuflor. }\end{array}$ & $\begin{array}{c}\text { Subgroup (Group B) } \\
\text { treated with Draxxin }\end{array}$ \\
\hline
\end{tabular}

\section{Results:-}

This study included the dead calves suffering from hematological examination and immunological analysis associated with each group as well as histopathological examination for

respiratory manifestation.

A-Diseased non- treated group Vs. control healthy group: 
Hematological results:-

The peripheral blood picture as illustrated in tables $(2,3)$ showed significant $(P \leq 0.05)$ decrease in RBCs count, $\mathrm{Hb}$ concentration, PCV value, lymphocytes count, eosinophil's count, basophils count and platelets count with non significant decrease in $\mathrm{MCHC}$ compared with control healthy group. Non- significant increase in $\mathrm{MCV}, \mathrm{MCH}$ with significant $(P \leq$ 0.05 ) increase in total leukocytic count, neutrophils and monocytes indicated anemia compared to control healthy group.

\section{Immunological}

parameters results:-

In the present work the diseased non- treated group showed significant $(P \leq 0.05)$ increase in both serum interleukin -6(IL-6) and tumor necrosis factor- $\alpha$ (TNF- $\alpha$ ) level with significant $(P \leq 0.05)$ decrease in both serum IgG and IgM level compared with the control healthy group. Table (4).

B- Diseased treated group with Nuflor Vs. Diseased non- treated group:

\section{Hematological results:-}

The diseased treated group with Nuflor (subgroup A) revealed significant $(P \leq 0.05)$ increase in both RBCs count, PCV, lymphocytes count, eosinophil's count, basophils count and platelets count with non- significant increase in $\mathrm{Hb}$ concentration and $\mathrm{MCHC}$ with non- significant decrease in both $\mathrm{MCV}$ and $\mathrm{MCH}$ values. A significant decrease $(P \leq 0.05)$ in total leukocytic count, neutrophils and monocytes count compared to diseased non- treated group. Tables $(2,3)$.

\section{Immunological}

parameters

\section{results:-}

The diseased treated group with Nuflor (subgroup A) revealed significant $(P \leq 0.05) \quad$ increase in both serum IgG and IgM levels with significant $(P \leq 0.05)$ decrease in both serum interleukin-6 (IL-6) and tumor necrosis factor- $\alpha$ (TNF- $\alpha$ ) levels compared to diseased nontreated group. Table (4).

C-Diseased treated group with Draxxin Vs. Diseased non- treated group:

\section{Hematological} results:-

The diseased treated group with Draxxin (subgroup B) revealed significant $(P \leq 0.05)$ increase in RBCS count, $\mathrm{Hb}$ concentration, PCV, lymphocytes count, eosinophil's count, basophils count and platelets count with nonsignificant increase in MCHC. A significant decrease in $\mathrm{MCV}, \mathrm{MCH}$, total leukocytic count, neutrophils and monocytes compared to diseased non- treated group. Tables $(2,3)$.

\section{Immunological}

results:-

The diseased treated group with Draxxin (subgroup B) showed significant $(P \leq 0.05)$ increase in both serum IgG and IgM levels with significant $(P \leq 0.05)$ decrease in both serum interleukin -6(IL-6) and 
tumor necrosis factor- $\alpha$ (TNF- $\alpha$ ) levels compared to diseased nontreated group. Table (4).

D-Nuflor treated group Vs. Draxxin treated group:Hematological results:

The results showed that diseased treated subgroup (B) that treated with draxxin showed improvement $\&$ significant $(P \leq 0.05)$ increase of RBCS count, $\mathrm{Hb}$ concentration, $\mathrm{PCV}$ and lymphocytes count with non- significant increase in MCHC, eosinophil's count, basophils count and platelets count. While showed non-significant decrease of $\mathrm{MCV}$ and $\mathrm{MCH}$ with significant $(P \leq 0.05)$ decrease in total leukocytic count, neutrophils count and monocytes count compared to diseased treated subgroup (A) that treated with Nuflor. Tables $(2,3)$.

\section{Immunological} results:-

In the present work the diseased treated subgroup (B) that treated with Draxxin showed improvement and significant $(P \leq 0.05)$ increase in both serum IgG and IgM levels with significant $(P \leq 0.05)$ decrease in both serums interleukin -6(IL-6) and tumor necrosis factor- $\alpha$ (TNFa) levels compared to diseased treated subgroup (A) that treated with Nuflor. Table (4).

\section{E-Histopathological findings} associated with calf pneumonia:

The lungs of dead calves with respiratory diseases were examined microscopically. The obtained results were lung edema (photo 1), hemorrhage, collapse (photo 2) and different types of pneumonia such as catarrhal (photo 3), suppurative, fibrinous (photo 4) and interstitial pneumonia (photo 5). Associated bronchial lymph nodes showing congestion of blood vessels and hyperplasia of lymphocyte cells (photo 6).

Table 2: Erythrocytic parameters in calves suffering from respiratory diseases before and after treatment with antibiotics (Nuflor \& Draxxin).

\begin{tabular}{|c|c|c|c|c|c|c|}
\hline Groups / Parameters & $\begin{array}{l}\text { RBCs } \\
\times 10^{6} / \mathrm{ml}\end{array}$ & $\begin{array}{c}\text { PCV } \\
\%\end{array}$ & $\begin{array}{l}\mathbf{H b} \\
\mathrm{g} / \mathrm{dl}\end{array}$ & $\begin{array}{c}\text { MCV } \\
\text { fl }\end{array}$ & $\begin{array}{c}\mathbf{M C H} \\
\mathrm{pg}\end{array}$ & $\underset{\%}{\text { MCHC }}$ \\
\hline Healthy control group & $\begin{array}{l}8.10^{\mathbf{a}} \pm \\
0.52\end{array}$ & $\begin{array}{l}32.50^{\mathrm{a}} \pm \\
0.52\end{array}$ & $\begin{array}{l}12.50^{\mathrm{a}} \pm \\
0.52\end{array}$ & $\begin{array}{l}43.75^{\mathbf{a}} \pm \\
2.82\end{array}$ & $\begin{array}{l}16.22^{\mathrm{a}} \pm \\
0.86\end{array}$ & $\begin{array}{l}38.19^{\mathbf{a}} \pm \\
1.12\end{array}$ \\
\hline $\begin{array}{c}\text { Diseased calves non- } \\
\text { treated }\end{array}$ & $\begin{array}{l}5.20^{\mathbf{c}} \pm \\
0.24\end{array}$ & $\begin{array}{l}24.07^{\mathbf{c}} \pm \\
0.59\end{array}$ & $\begin{array}{l}8.57^{\mathbf{b}} \pm \\
0.28\end{array}$ & $\begin{array}{l}48.50^{\mathbf{a b}_{ \pm}} \\
2.79\end{array}$ & $\begin{array}{l}18.17^{\mathbf{a b}_{ \pm}} \\
0.98\end{array}$ & $\begin{array}{l}35.77^{\mathbf{a}_{ \pm}} \\
1.13\end{array}$ \\
\hline $\begin{array}{l}\text { Diseased calves treated } \\
\text { with Nuflor }\end{array}$ & $\begin{array}{l}6.30^{\mathbf{b}} \pm \\
0.30\end{array}$ & $\begin{array}{l}27.41^{\mathbf{b}_{ \pm}} \\
0.49\end{array}$ & $\begin{array}{l}10.10^{\mathbf{b}_{ \pm}} \\
0.28\end{array}$ & $\begin{array}{l}47.51^{\mathbf{a}_{ \pm}} \\
4.26\end{array}$ & $\begin{array}{l}17.64^{\mathbf{a}_{ \pm}} \\
0.84\end{array}$ & $\begin{array}{l}36.81^{\mathbf{a}_{1}} \\
1.27\end{array}$ \\
\hline $\begin{array}{l}\text { Diseased calves treated } \\
\text { with Draxxin }\end{array}$ & $\begin{array}{l}7.33^{\mathrm{a}} \pm \\
0.40\end{array}$ & $\begin{array}{l}30.44^{\mathrm{a}} \pm \\
0.52\end{array}$ & $\begin{array}{l}11.19^{\mathrm{a}} \pm \\
0.38\end{array}$ & $\begin{array}{l}43.93^{\mathbf{a c}} \pm \\
3.01\end{array}$ & $\begin{array}{l}16.62^{\mathrm{ac}} \pm \\
0.71\end{array}$ & $\begin{array}{l}38.12^{\mathrm{a}} \pm \\
2.19\end{array}$ \\
\hline
\end{tabular}

Means within each comparison in the same column with the different superscripts differ significantly $(P \leq 0.05)$. 
Table 3: Leukogram picture in calves suffering from respiratory diseasesbefore and after treatment with antibiotics (Nuflor\&Draxxin).

\begin{tabular}{|c|c|c|c|c|c|c|c|}
\hline $\begin{array}{c}\text { Groups / } \\
\text { Parameters }\end{array}$ & $\begin{array}{l}\text { T.L.C } \\
\times 10^{3} / \mathrm{ml}\end{array}$ & $\begin{array}{c}\text { Neutrophil } \\
\%\end{array}$ & $\begin{array}{c}\text { Lymphocytes } \\
\%\end{array}$ & $\begin{array}{c}\text { Monocytes } \\
\%\end{array}$ & $\begin{array}{c}\text { Eosinophil's } \\
\%\end{array}$ & $\begin{array}{c}\text { Basophils } \\
\%\end{array}$ & $\begin{array}{l}\text { Plateles } \\
\times 1 .\ulcorner/ \mathrm{ml}\end{array}$ \\
\hline $\begin{array}{l}\text { Healthy control } \\
\text { group }\end{array}$ & $\begin{array}{l}10.95 \pm \\
0.98\end{array}$ & $\begin{array}{c}46.55^{\mathbf{d}_{ \pm}} \\
0.43\end{array}$ & $\begin{array}{c}45.85^{\mathbf{a}_{ \pm}} \\
0.41\end{array}$ & $\begin{array}{c}1.85^{\mathrm{d}_{ \pm}} \\
0.16\end{array}$ & $\begin{array}{c}2.24^{\mathrm{a}} \pm \\
0.28\end{array}$ & $\begin{array}{c}3.57^{\mathrm{a}} \pm \\
0.34\end{array}$ & $\begin{array}{c}700.00^{\mathrm{a}} \pm \\
0.52\end{array}$ \\
\hline $\begin{array}{c}\text { Diseased calves } \\
\text { non-treated }\end{array}$ & $\begin{array}{c}16.12^{\mathbf{a}_{ \pm}} \\
0.63\end{array}$ & $\begin{array}{c}59.85^{\mathbf{a}_{ \pm}} \\
1.45\end{array}$ & $\begin{array}{c}31.85^{\mathrm{d}_{ \pm}} \\
1.35\end{array}$ & $\begin{array}{c}5.40^{\mathrm{a}_{ \pm}} \\
0.28\end{array}$ & $\begin{array}{c}0.84^{\mathbf{c}} \pm \\
0.10\end{array}$ & $\begin{array}{c}2.23^{\mathbf{b}_{ \pm}} \\
0.12\end{array}$ & $\begin{array}{c}641.80^{\mathrm{d}_{ \pm}} \\
9.34\end{array}$ \\
\hline $\begin{array}{l}\text { Diseased calves } \\
\text { treated with } \\
\text { Nuflor }\end{array}$ & $\begin{array}{c}14.49^{\mathbf{b}_{ \pm}} \\
0.57\end{array}$ & $\begin{array}{c}54.87^{\mathbf{b}_{ \pm}} \\
1.24\end{array}$ & $\begin{array}{c}37.05^{\mathbf{c}_{ \pm}} \\
1.10\end{array}$ & $\begin{array}{c}3.84^{\mathbf{b}_{ \pm}} \\
0.24\end{array}$ & $\begin{array}{c}1.31^{\mathbf{b}_{ \pm}} \\
0.20\end{array}$ & $\begin{array}{c}2.92^{\mathrm{a}} \pm \\
0.32\end{array}$ & $\begin{array}{c}652.55^{\mathbf{c}} \pm \\
8.24\end{array}$ \\
\hline $\begin{array}{l}\text { Diseased calves } \\
\text { treated with } \\
\text { Draxxin }\end{array}$ & $\begin{array}{c}13.11^{\mathbf{c}_{ \pm}} \\
0.47\end{array}$ & $\begin{array}{c}50.80^{\mathbf{c}_{ \pm}} \\
1.16\end{array}$ & $\begin{array}{c}41.35^{\mathbf{b}_{ \pm}} \\
0.82\end{array}$ & $\begin{array}{c}2.79^{c_{ \pm}} \\
0.16\end{array}$ & $\begin{array}{c}1.98^{\mathbf{a b}_{ \pm}} \\
0.31\end{array}$ & $\begin{array}{c}3.07^{\mathrm{a}_{ \pm}} \\
0.37\end{array}$ & $\begin{array}{c}664.55^{\mathbf{b c}_{ \pm}} \\
7.31\end{array}$ \\
\hline
\end{tabular}

Means within each comparison in the same column with the different superscripts differ significantly $(P \leq 0.05)$.

Table 4: Immunological parameters in calves suffering from respiratory diseases before and after treatment with antibiotics (Nuflor \& Draxxin).

\begin{tabular}{|c|c|c|c|c|}
\hline Groups / Parameters & $\begin{array}{l}\mathbf{I g G} \\
\mathrm{gm} / \mathrm{dl}\end{array}$ & $\underset{\mathrm{gm} / \mathrm{dl}}{\operatorname{IgM}}$ & $\begin{array}{l}\text { TNF- } \alpha \\
\mathrm{pg} / \mathrm{ml}\end{array}$ & $\begin{array}{l}\text { IL-6 } \\
\mathrm{pg} / \mathrm{ml}\end{array}$ \\
\hline Healthy control group & $\begin{array}{l}1.3^{\mathrm{a}} \pm \\
0.06\end{array}$ & $\begin{array}{l}1.1^{\mathrm{a}_{ \pm}} \\
0.05\end{array}$ & $\begin{array}{l}52.83^{\mathrm{d}} \pm \\
1.85\end{array}$ & $\begin{array}{c}244.28^{\mathrm{d}} \pm \\
2.66\end{array}$ \\
\hline Diseased calves non treated & $\begin{array}{c}0.92^{\mathrm{d}_{ \pm}} \\
0.11\end{array}$ & $\begin{array}{c}0.73^{\mathrm{d}_{ \pm}} \\
0.04\end{array}$ & $\begin{array}{c}143.84^{\mathbf{a}_{ \pm}} \pm \\
2.99\end{array}$ & $\begin{array}{l}375.91^{\mathbf{a}} \pm \\
8.10\end{array}$ \\
\hline $\begin{array}{l}\text { Diseased calves treated with } \\
\text { Nuflor }\end{array}$ & $\begin{array}{c}1.01^{\mathbf{c}_{1}} \\
0.08\end{array}$ & $\begin{array}{c}0.77^{\mathfrak{c}_{ \pm}} \\
0.04\end{array}$ & $\begin{array}{c}118.51^{b} \pm \\
2.56\end{array}$ & $\begin{array}{c}299.55^{\mathbf{b}} \pm \\
10.49\end{array}$ \\
\hline $\begin{array}{c}\text { Diseased calves treated with } \\
\text { Draxxin }\end{array}$ & $\begin{array}{l}1.1^{\mathbf{b}} \pm \\
0.04\end{array}$ & $\begin{array}{c}0.84^{\mathbf{b}} \pm \\
0.48\end{array}$ & $\begin{array}{c}88.40^{\mathbf{c}} \pm \\
1.74\end{array}$ & $\begin{array}{l}259.79^{\mathbf{c}} \pm \\
2.99\end{array}$ \\
\hline
\end{tabular}

Means within each comparison in the same column with the different superscripts differ significantly $(P \leq 0.05)$.
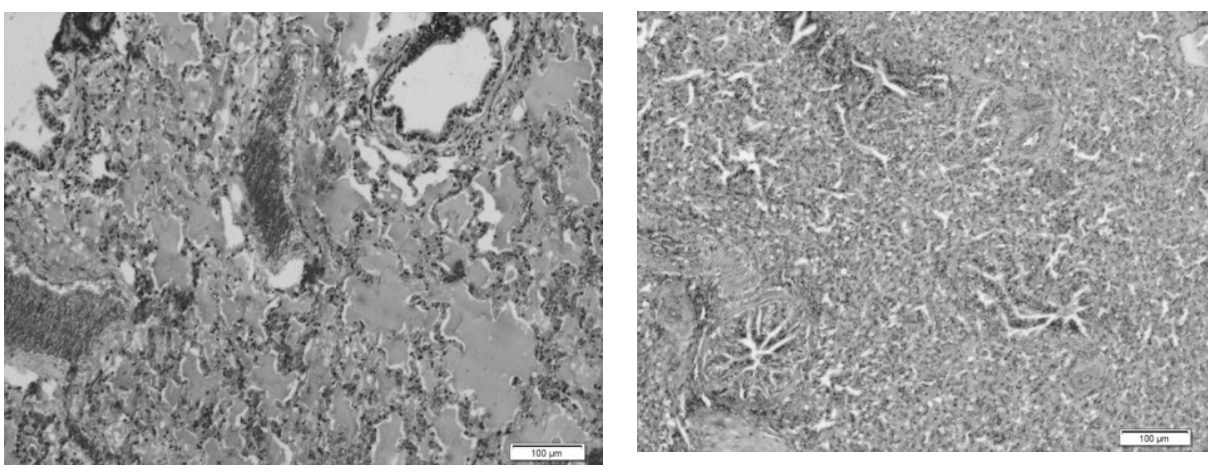
Photo 1: Lung showing massive alveolar edema along with congestion of blood vessels. $H \& E . X 200$.
Photo 2: lung showing collapsed alveoli, most bronchioles are collapsed filled with homogenous material. H\&E. X 100.

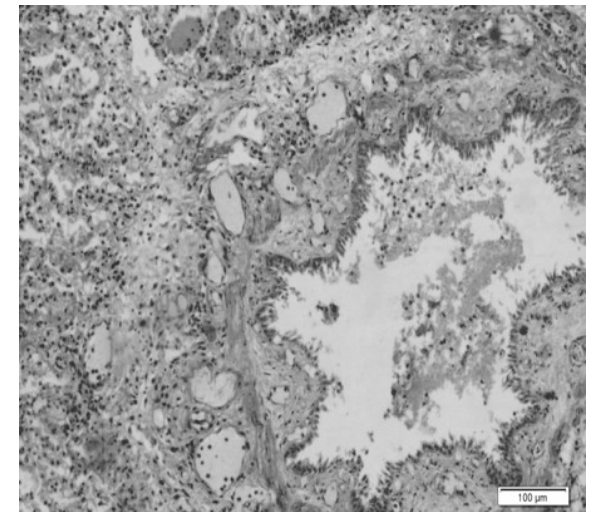

Photo 3: lung showing bronchitis, catarrhal exudates admixed with neutrophils inside the lumen, alveoli filled with serofibrinous exudates and neutrophilic infiltration. H\&E.X 200.

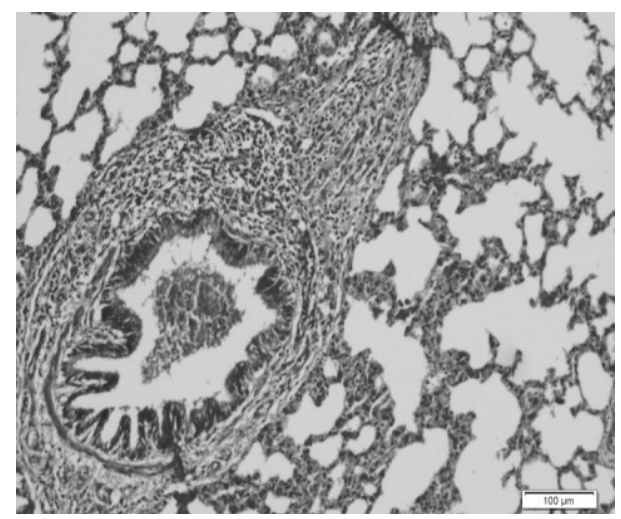

Photo 5: Lung showing bronchiolitis, peribroncholitis, mononuclear cell infiltration \& mild interstitial pneumonia. $H \& E$. X 200.

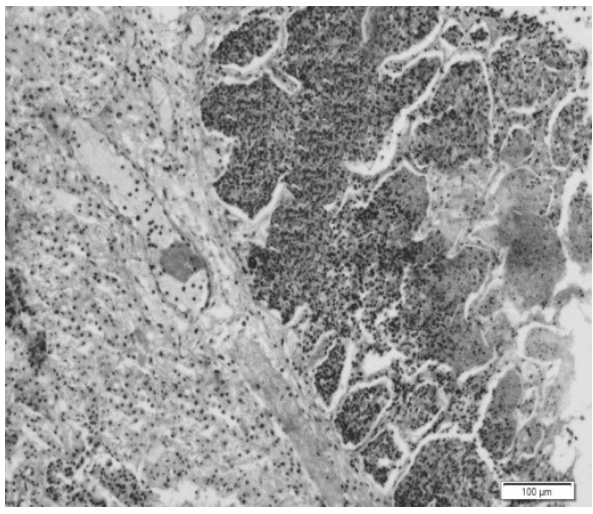

Photo 4: Lung showing massive infiltration with neutophiles and serofibinous exudation. H\&E. X 200.

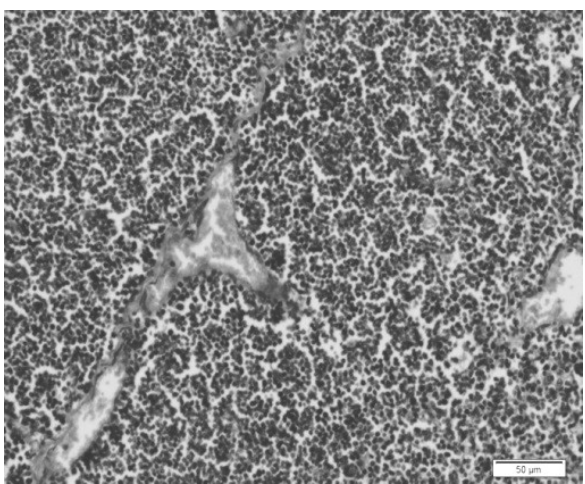

Photo 6: Lymph node showing congestion of blood vessels \& hyperplasia of lymphocyte cells. H\&E. X 200. 
Discussion:-

Bovine respiratory disease is the most common illness affecting housed cattle and it is a major limiting factor in animal production .In addition to the economic loss, high morbidity respiratory disease also represents a significant animal welfare issue Healy et al (1993). The hematological investigation in diseased non- treated group revealed decrease in erythrocytic count, hemoglobin concentration, and hematocrit (PCV) value indicated anemia. This result is in agreement with Khodary and Rizk (2000). The decrease in the RBCs count, $\mathrm{Hb}$ concentration and $\mathrm{PCV}$ value were due to the effect of pathogens toxins on the RBCs which cause damage and destruction (Coles, 1986). The neutrophilic leukocytosis may be attributed to the response of the leukogram to inflammatory lung diseases caused by pathogens infection Duncan and Prasse (1986). The results of blood indices showed anemia this due to destruction of RBCs by pathogens toxins which lead to hemoglobin breakdown and RBCs hemolysis (Karaivanov, 1984). The hematological findings in subgroup (A) and subgroup (B) which treated with Nuflor \& Draxxin showed increase in RBCs count, $\mathrm{Hb}$ concentration and $\mathrm{PCV} \%$ compared to diseased non- treated group. This is in agreement with Khodary and Rizk (2000) who used Nuflor as a therapeutic dose for treatment of bovine respiratory infection and found that treated calves developed enhancement in erythrocytic parameters. The leukogram of the diseased non- treated group in the present study showed leukocytosis with neutrophilia. This indicating presence of inflammation caused by infection (Coles, 1986). Our findings were in agreement with Naglaa et al (2014). Calves of subgroups (A) \& (B) which treated with antibiotics (Nuflor \& Draxxin) showed an improvement in leukogram parameters compared with the diseased non- treated group indicating favorable response to the treatment. These findings are in agreement with Sabry and wael (2013) Khodary and Rizk (2000) who reported that treated calves which was infected with bovine respiratory infection and treated with Nuflor revealed improvement in leukogram parameters.The present work demonstrates thrombocytopenia in diseased nontreated group. These is in agreement with Nyarko et al (1998). These results may be attributed to direct destruction of platelets by the pathogens and increase thrombocytes adhesion and platelets binding to vascular endothelium damaged by the pathogens action as reported by Wilson (1982). The platelets counts in subgroup (B) treated with Draxxin showed increase than the diseased nontreated group and diseased treated subgroup (A) with Nuflor. These 
results may be attributed to potent effect of Draxxin to improve the platelets picture as recorded by Ragbetli et al (2009). The cytokines groups are the primary inducers of acute phase protein APP gene expression and each type initiates a different pattern of APP Baumann and Gauldie (1994). Thus the increase in different pattern of acute phase protein APP reflected the production of different amounts or types of cytokines.In the present study the tumor necrosis factor $\alpha$ (TNF- $\alpha$ ) and interleukin 6 (IL-6) were detected to be increased in the bovine respiratory diseases (BRD) affected calves compared to the control healthy group. This result is similar to Gruys et al (2005) Who concerning such elevated level of tumor necrosis factor $\alpha$ (TNF- $\alpha)$ and interleukin 6 (IL-6) in inflammation and infection were observed in cattle. These results may be due to tumor necrosis factor $\alpha(\mathrm{TNF}-\alpha)$ is an inflammatory cytokine produced by macrophage during acute inflammation and is responsible for a diverse range of signaling events within cells Howard (1990). In the present work the diseased treated subgroups (A\&B) which treated with antibiotics (Nuflor and Draxxin) showed decrease in both serums TNF- alpha and IL-6 levels compared to diseased non- treated group. This due to antibiotic treatments may interfere with cytokine production. This result is in agreement with Khan et al
(2000) who reported that fluoroquinolones reduced the serum TNF- alpha and IL-6 concentration in LPS treated mice. In this present study the calves suffered from a respiratory disease (diseased nontreated group) showed low level of both serum immunoglobulin $\mathrm{G}$ (IgG) and immunoglobulin $\mathrm{M}$ (IgM) compared to control healthy ones. This result is attributed to insufficiently provided colostrum or received colostrum feeding to newborn calves this lead to decrease the serum Ig concentration and failure receiving antibodies via passive immunization with colostrum intake. These results agree with Quigley et al (1995). The diseased treated subgroups (A\&B) which treated with antibiotics (Nuflor and Draxxin) showed an increase in both serum IgG\&IgM levels and decreases in cytokines production levels (TNF- $\alpha$ and IL-6 ) this results may be attributed to integrating systemic responses. Balancing antibacterial / antiviral host defenses and inflammatory injury caused by pneumonia. The histopathological lesions of lung showed lung edema, hemorrhage, collapse and different types of pneumonia such as catarrhal, suppurative, fibrinous and interstitial pneumonia and this picture was mentioned by Ngatia et al (1986) and Abd El- Kader (1992) who recorded that this results may be due to different microrganisms and/or due to inflammation caused by long 
duration of mild irritation of lung tissue, pyogenic microrganisms and associated lymph nodes which showed hyperplasia of lymphoid tissue, congestion of blood vessels and focal depletion of lymphocytes.

\section{References:-}

Abd-El-Kader H.A. (1992): Studies on bacterial and parasitic causes of respiratory infections among dairy animals .Ph.D thesis Dept.of Animal Medicine, Faculty of Veterinary Medicine, Assiut Univeristy.

Autio T., Pohjanvihrta T., Hllopainen R., Rikula U., Pentikaine J., Huovllainen A., Rusanen H., Soveri T., Sihvonen L. and Pelkonen S. (2007): Etiology of respiratory disease in non-vaccinated, nonmedicated calves in rearing herds. Vet. Microbiol.; 31: 256-265.

Baumann H. and J. Gauldie (1994): The acute phase response. Immunol. Today, 15: 74-80. PMID: 7512342.

Chan E. and Perlstein A. (1987): Immunoassay:A partical guide Academic press: Newyork USA.

Coles E.H. (1986): Textbook of veterinary clinical pathology. 4th ed. W. B. Sounders Co; Philadelphia, London.

Drury R. and Willington E.S. (1980): Carleton's histological technique". 5 th ed.

Duncan J.R. and Prasse K.W. (1986): Veterinary Laboratory Medicine-Clinical pathology 2nd Ed.; Iowa State Univ. press, Ames, Iowa, USA.

Dytham C. (1999): Choosing and Using Statistics: A Biologist's Guide. Blackwell Science Ltd.; London, UK.

Feldman B.F., Zinkl J.G. and Jain (2000): Schalms Veterinary
Hematology .5th ed.Lippincot Williams and Wilkins.Canada; P: 1145-1146.

Griffin D., Chengappa M.M., Kuszak J. and Mevey D.S. (2010): Bacterial pathogens of the bovine respiratory disease complex. Vet Clin. North Am. Food Anim. Pract.; 26: 381394.

Gruys E., Toussaint M.J., Upragarin N., Van E.A. and Adewuyi A.A. et al., (2005): Acute phase reactants, challenge in the near future of animal production and Veterinary medicine. J. Zhejiang Univ. Sci.; 6: 941-947. DOI: 10.1631/jzus.B0941.

Healy A.M., Monaghan M.L., Bassett H.F., Gunn H.M.,Markey B.K. and Collins J.D. (1993): Morbidity and mortality in a large Irish feedlot: microbiological and serological findings in cattle with acute respiratory disease. British Veterinary Journal 149: 549-560.

Howard C.J. (1990): Immunological responses to bovine virus diarrhoea virus infections. Rev. Sci. Tech.; 9: 95103.

Jain N.C. (1986): Schalm's Veterinary Hematology. 4th ed. Lea and Fehiger, Philadelphia, USA.

Jovin T.N., Dante M.L. and Chrombach A. (1971): Fractionation of serum proteins. U.S.Gor, Res. and Dev. Reports.; PP.196085-196092.

Karaivanov L. (1984): biochemical tests for identifying pasteurella multocida. Vet. Med. Neuki. 21(9):3844.

Khan A.A., Slifer T.R., Araujo F.G., Suzuki Y. and Remington J.S. (2000): Protection against lipopolysaccharide-induced death by fluoroquinolones Antimicrob. Agents Chemother.; 44: 3169-3173. 
Khodary R.M. and Rizk H.I. (2000): Effect of florofenicol on some blood constituents of buffalo calves. Vet. Med. Res. Vol.II, No.1: 93-102.

Malazdrewich C., Ames T.R., Abrahamsen M.S. and Maheswaran S.K. (2001): Pulmonary expression of tumor necrosis factor alpha, interleukin-1 beta, and interleukin-8 in the acute phase of bovine pneumonic Pasteurellosis. Vet. Pathol.; 38: 297310.

Naglaa Eleiwa Z.H., Gehan Gad N.A. and Amal El-Shorbagy I.A. (2014): Effect of a combined Oxytetracycline $\mathrm{HCl}$

Flunixinmeglumine therapy on undifferentiated respiratory disease in calves. International Journal of Advanced Research Volume 2, Issue 3 : 387-398.

Ngatio T.A., Kimberling C.V., Johnson L.W., Whiteman C.E. and Lauermann L.H. (1986): Pneumonia in goats following administration of live and heated- killed pasturalla haemolytica.J.Comp .Path,96 (5):557564.

Nyarko K.A., Coombe B.L., Mellors A. and Gentry P.A. (1998): Bovine platelets adhesion in enhanced by the leukotoxin and sialoglycoprotease isolated from pasteurella haemolytica A1 cultures .Vet. Microbial Mar, 15; 16(1-2):81-91.

Quigley J.D., Martin K.R., Bemis D.A., Potgieter L.N.D., Reinemeyer
C.R., Dowlen H.H. and Lamar K.C. (1995): Effects of housing and colostrum feeding on serum immunoglobulins, growth and fecal scores of yersey calves. J. Dairy. Sci.; 78:893-901.

Ragbetli, Tanritanir P., Yoruk I. and Cay M. (2009): The effect of tulathromycin treatment on antioxidant vitamins in montofen calves with pneumonia .Journal of animal and veterinary Advances 8(11):2345-2349.

Sabry El-Bahr M. and Wael ELDeeb M. (2013): acute phase protein, lipid profile and pro-inflammatory cytokines in healthy and bronchopeumonic water buffalo calves. American Journal of Biochemistry and Biotechnology, 9 (1): 34-40.

Soethout E.C., Muller K.E. and Rutten V.P. (2002): Neutrophil migration in the lung: General and bovine-specific aspects. Vet. Immunol. Immunopathol.; 87: 277-285. DOI: 10.1016/S0165-2427(02)00053-3.

Trinchieri G. (2003): Interleukin-12 and the regulation of innate resistance and adaptive immunity. Nat. Rev. Immunol.; 3: 133-146. DOI: 10.1038/nri1001.

Wajant H., Pfizenmaier K. and Scheurich P. (2003): "Tumor necrosis factor signaling". Cell Death Differ. 10 (1): 45-65.

Wilson J.J. (1982): Infection induced thrompocytopenia semin thromb.Hemostas. 8:217. 


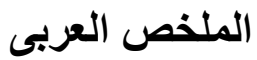 \\ "دراسات باثولوجية أكلينيكية على بعض الامراض التنفية فى العجول الجاموسى الملى \\ حيثة الولادة " الادراض \\ أسامة على محمد عبد الله ، أمنية السيد كيلانى ،أمينة على دسوقى ،نيهال عبد الرحيم محمود}

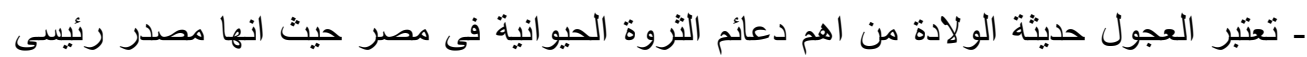

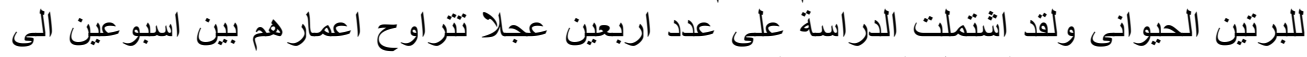

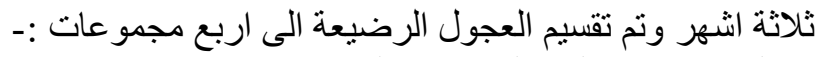
- (المجمو عة الاولى ) المجمو عة الضابطة.

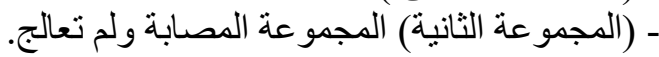

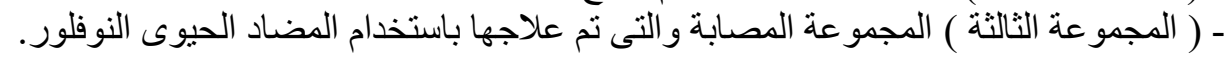

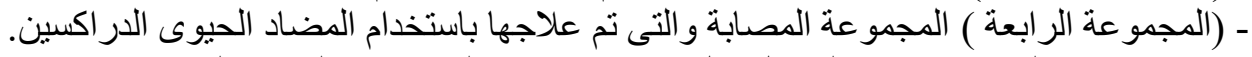

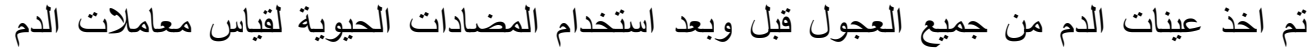
و المعاملات المناعية وكذلك اخذت عينات من الرئة و الغدد الليمفاوية الملحقة بها وقد اسفرت الترات النتائج

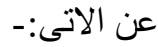

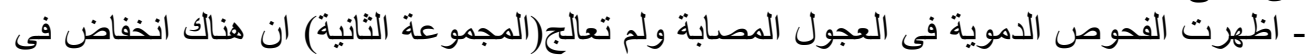

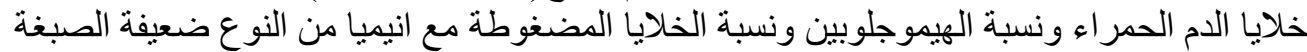

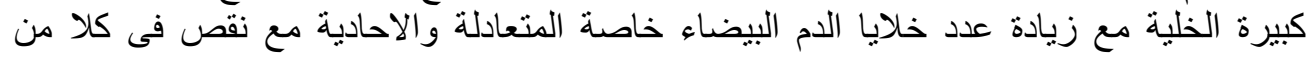

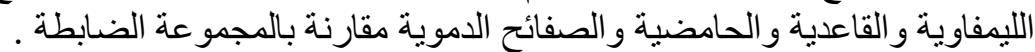

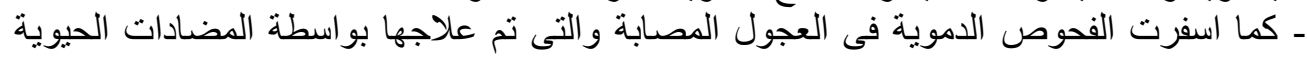

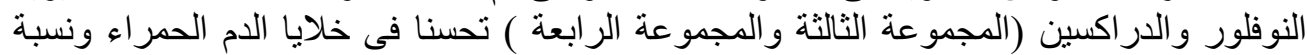

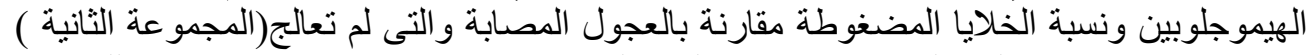

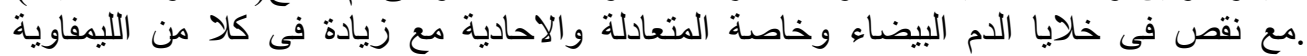

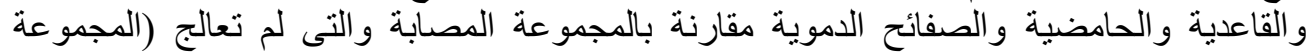

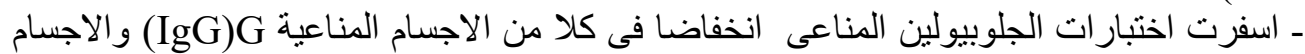

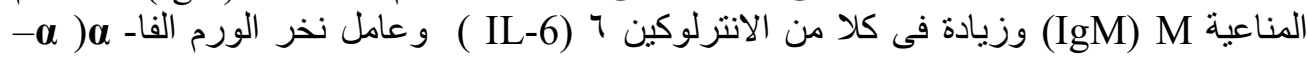
(TNF-

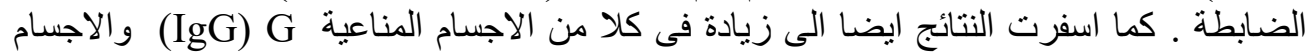

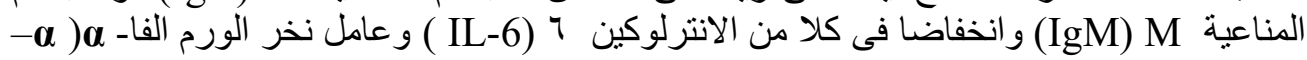
(TNF-

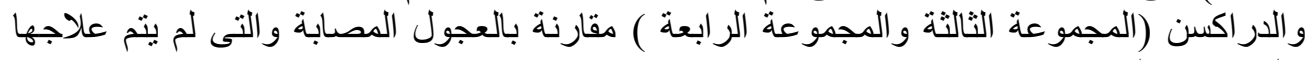

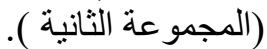

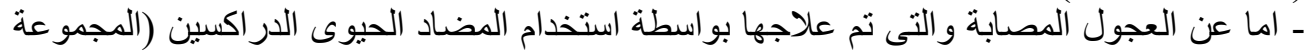

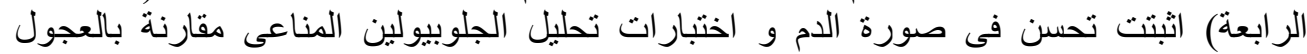

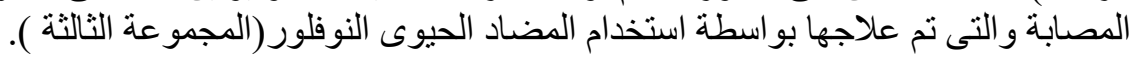

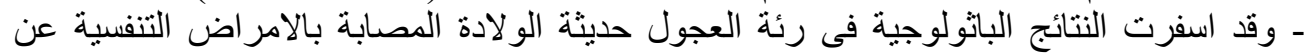

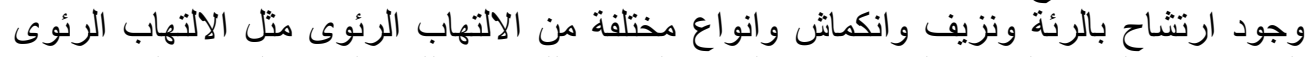

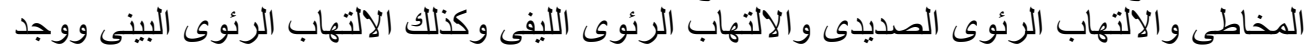
ايضا احتقان فى الاو عية الدموية فى الغدد الليفاوية الرئوية مع زيادئ في الإنى عدد الخلايا الليفاوية. 